\title{
Gastric Mucus Secretion Induction
}

National Cancer Institute

\section{Source}

National Cancer Institute. Gastric Mucus Secretion Induction. NCI Thesaurus. Code C41563.

Gastric Mucus Secretion Induction involves stimulation of mucus release from gastric cells into the lumen of the stomach. Stimulation promotes mucous protection and lubrication of the stomach. 